\title{
Atmospheric ammonia and particulate ammonium from agricultural sources in the North China Plain
}

\author{
Jianlin Shen ${ }^{\mathrm{a}, \mathrm{b}}$, Xuejun Liu ${ }^{\mathrm{a}, \mathrm{c}, *}$, Ying Zhang ${ }^{\mathrm{a}}$, Andreas Fangmeier ${ }^{\mathrm{d}}$, Keith Goulding ${ }^{\mathrm{e}}$, Fusuo Zhang ${ }^{\mathrm{a}}$ \\ ${ }^{a}$ College of Resources and Environmental Sciences, China Agricultural University, Beijing 100193, China \\ ${ }^{\mathrm{b}}$ Institute of Subtropical Agriculture, Chinese Academy of Sciences, Changsha 410125, China \\ ${ }^{\mathrm{c}}$ Key Laboratory of Biogeography and Bioresource in Arid Land, Xinjiang Institute of Ecology and Geography, Chinese Academy of Sciences, Urumqi 830011, China \\ ${ }^{\mathrm{d}}$ Institute for Landscape and Plant Ecology, University of Hohenheim, 70593 Stuttgart, Germany \\ ${ }^{\mathrm{e}}$ Department of Soil Science, Rothamsted Research, Harpenden, Herts, AL5 2JQ UK
}

\section{A R T I C L E I N F O}

\section{Article history:}

Received 6 July 2010

Received in revised form

8 January 2011

Accepted 15 February 2011

\section{Keywords:}

Ammonia emission

Secondary particle

$\mathrm{PM}_{10}$

Nitrogen deposition

\begin{abstract}
A B S T R A C T
Atmospheric ammonia $\left(\mathrm{NH}_{3}\right)$ and particulate ammonium $\left(\mathrm{NH}_{4}^{+}\right)$were measured using passive samplers and particulate samplers at four rural and two suburban sites in the North China Plain (NCP) from August 2006 to September 2009. The annual mean concentrations of $\mathrm{NH}_{3}$ and $\mathrm{NH}_{4}{ }^{+}$in $\mathrm{PM}_{10}$ across the sites were 15.6 and $12.4 \mathrm{\mu g} \mathrm{m}^{-3}$, respectively. Higher concentrations of $\mathrm{NH}_{3}$ and $\mathrm{NH}_{4}{ }^{+}$were found at the rural sites compared with the suburban sites. $\mathrm{NH}_{3}$ concentrations were highest in summer and lowest in winter, showing positive correlations with $\mathrm{N}$ fertilizer application rates and temperature in each season. Particulate $\mathrm{NH}_{4}^{+}$showed significant positive correlations with particulate $\mathrm{SO}_{4}{ }^{2-}$ and $\mathrm{NO}_{3}{ }^{-}$at the six sites. The annual mean concentrations of secondary inorganic particles (sum of $\mathrm{NH}_{4}{ }^{+}, \mathrm{SO}_{4}{ }^{2-}$ and $\mathrm{NO}_{3}{ }^{-}$) accounted for $26.1-41.3 \%$ of the $\mathrm{PM}_{10}$ concentration across all sites. The formation of inorganic $\mathrm{NH}_{4}{ }^{+}$ particles was limited mainly by the availability of $\mathrm{H}_{2} \mathrm{SO}_{4}$ and $\mathrm{HNO}_{3}$ and partly by $\mathrm{NH}_{3}$. The total $\mathrm{NH}_{\mathrm{X}}$ deposition in the NCP averaged $43.5 \mathrm{~kg} \mathrm{~N} \mathrm{ha}^{-1} \mathrm{yr}^{-1}$, accounting for $84.1 \%$ of the mean $\mathrm{NH}_{3}$ emission intensity. The serious particulate $\mathrm{NH}_{4}{ }^{+}$pollution and high $\mathrm{NH}_{\mathrm{x}}$ deposition suggest the urgency of reducing $\mathrm{NH}_{3}$ emission from agricultural sources in the NCP.
\end{abstract}

(c) 2011 Elsevier Ltd. All rights reserved.

\section{Introduction}

Ammonia $\left(\mathrm{NH}_{3}\right)$ is the most abundant basic gas in the atmosphere. The primary sources for atmospheric $\mathrm{NH}_{3}$ are agricultural emissions such as domestic animals, nitrogen $(\mathrm{N})$ fertilizer application and biomass burning (Bouwman et al., 1997; Galloway et al., 2004). Once emitted to the atmosphere, $\mathrm{NH}_{3}$ will deposit onto the earth's surface near sources in large quantities as dry deposition. Ammonia can also react with acidic species (e.g., $\mathrm{H}_{2} \mathrm{SO}_{4}, \mathrm{HNO}_{3}, \mathrm{HCl}$ ) to form secondary inorganic particles (e.g., $\left(\mathrm{NH}_{4}\right)_{2} \mathrm{SO}_{4}, \mathrm{NH}_{4} \mathrm{NO}_{3}$, and $\mathrm{NH}_{4} \mathrm{Cl}$ ) (Asman et al., 1998). These secondary particles have been regarded as the main contributor to fine particulate matter (PM), which is harmful to human health and reduces visibility (Erisman and Schaap, 2004; Pinder and Adams, 2007) and is also implicated in climate change due to its effects on direct and indirect radiative forcing (Adams and Seinfeld, 2001; Haywood and Boucher, 2000). The deposition of $\mathrm{NH}_{3}$ and particulate ammonium $\left(\mathrm{NH}_{4}{ }^{+}\right)$in natural

\footnotetext{
* Corresponding author. College of Resources and Environmental Sciences, China Agricultural University, Beijing 100193, China.

E-mail address: liu310@cau.edu.cn (X. Liu).
}

or semi-natural ecosystems may cause eutrophication, soil acidification and loss of biodiversity (Bergström and Jansson, 2006; Bouwman et al., 2002; Stevens et al., 2004).

Due to the negative effects on the environment, environmental scientists have concentrated on atmospheric ammonia and particulate ammonium since the 1990s (Sutton et al., 2008). Concentrations of atmospheric $\mathrm{NH}_{3}$ and $\mathrm{pNH}_{4}{ }^{+}$have been measured at many sites worldwide to check pollution levels and estimate dry deposition fluxes as well as for calibrating deposition models (e.g., Erisman and Schaap, 2004). For example, the mean concentration of $\mathrm{NH}_{3}$ was as high as $10.48 \mu \mathrm{g} \mathrm{m}^{-3}$ at a commercial hog farm in eastern North Carolina, USA (McCulloch et al., 1998). In comparison, mean $\mathrm{NH}_{\mathrm{x}}$ $\left(\mathrm{NH}_{3}+\mathrm{NH}_{4}^{+}\right)$concentration was only $2.21 \mu \mathrm{g} \mathrm{m}{ }^{-3}$ at Mt. Mitchell, NC, USA (Aneja et al., 1998). Walker et al. (2004) reported $\mathrm{NH}_{\mathrm{x}}$ concentrations being $7.16,3.71$ and $1.49 \mu \mathrm{g} \mathrm{m}^{-3}$ at sites located in counties with total $\mathrm{NH}_{3}$ emission densities of $48.0,22.8$ and $3.20 \mathrm{~kg}$ $\mathrm{NH}_{3}-\mathrm{N} \mathrm{ha}^{-1} \mathrm{yr}^{-1}$, respectively. Measuring $\mathrm{NH}_{3}$ and $\mathrm{pNH}_{4}{ }^{+}$is time consuming, complicated and costly, but recently, Clarisse et al. (2009) found that infrared spectra, obtained by the IASI/MetOp satellite can be used to map global $\mathrm{NH}_{3}$ concentrations from space. Though this method needs much improvement, it offers a new and easier way to check $\mathrm{NH}_{3}$ pollution levels over large regions. 
In previous studies, we found very high $\mathrm{NH}_{3}$ emission intensities (from 40 to $120 \mathrm{~kg} \mathrm{~N} \mathrm{ha}^{-1} \mathrm{yr}^{-1}$ ) in the North China Plain (NCP), which were mainly caused by high $\mathrm{NH}_{4}$-based fertilizer application rates and large numbers of intensive livestock farms (Cai et al., 2004; Yan et al., 2003; Zhang et al., 2010). Such high emission intensities may consequently cause high $\mathrm{NH}_{3}$ concentrations and pollution. Considering the concomitant large emission intensities of both $\mathrm{SO}_{2}$ and $\mathrm{NO}_{\mathrm{x}}$ in this region (Lu et al., 2010; Richter et al., 2005; Streets and Waldhoff, 2000), we suspect that secondary inorganic particle pollution due to the reaction between $\mathrm{NH}_{3}$ and acids from $\mathrm{SO}_{2}$ and $\mathrm{NO}_{\mathrm{x}}$ could be a major problem. High bulk deposition of reduced $\mathrm{N}$ has partly proved this (e.g., Liu et al., 2006; Zhang et al., 2008).

Croplands account for about $60 \%$ of the NCP. Therefore, $\mathrm{NH}_{3}$ emission from $\mathrm{N}$ fertilized croplands will have a very important influence on local air quality and pollution. However, direct measurements of atmospheric $\mathrm{NH}_{3}$ and $\mathrm{NH}_{4}{ }^{+}$concentrations are scarce. In this paper, we present measurements of atmospheric $\mathrm{NH}_{3}$ and particulate $\mathrm{NH}_{4}{ }^{+}$as well as particulate $\mathrm{NO}_{3}{ }^{-}, \mathrm{SO}_{4}{ }^{2-}$ and $\mathrm{Cl}^{-}$ concentrations at six typical sites in the NCP. The spatio-temporal characteristics of the measured compounds, correlations between particulate $\mathrm{NH}_{4}{ }^{+}$and particulate $\mathrm{NO}_{3}{ }^{-}, \mathrm{SO}_{4}{ }^{2-}$ and $\mathrm{Cl}^{-}$as well as the $\mathrm{NH}_{3} / \mathrm{NH}_{\mathrm{x}}$ ratios were analyzed. The emission, transport, transformation and deposition of $\mathrm{NH}_{\mathrm{X}}$ and the benefits from agricultural $\mathrm{NH}_{3}$ emission controls in reducing the PM pollution in this intensively managed agricultural region are discussed.

\section{Materials and methods}

\subsection{Sampling sites}

Six monitoring sites were selected based on land use categories, distance from the city, and $\mathrm{NH}_{3}$ emission intensity. The six sites were Dongbeiwang (DBW), Shangzhuang (SZ), Quzhou (QZ), Huimin (HM), Wuqiao (WQ) and Shouguang (SG), and their locations are shown in Fig. 1. The $\mathrm{NH}_{3}$ emission intensities in the year 2008 in a $5 \mathrm{~km} \times 5 \mathrm{~km}$ resolution for each site, calculated with the census database from China's statistic datasets and emission factors recalculated by the RAINS model (Zhang et al., 2010), are shown in Table 1.

Both DBW and SZ are suburban sites in the northwest suburb of Beijing. They are 20 and $33 \mathrm{~km}$ away from the city center of Beijing, respectively. Croplands account for about $40 \%$ of the total land area; other main land uses are residential, commercial houses, small scale livestock farms and roads. The DBW and SZ sites were surrounded by agricultural fields growing mainly winter wheat and summer maize in rotation. The unique difference between the two locations is that $\mathrm{SZ}$ is far from a main road (c $2 \mathrm{~km}$ ) while DBW is much closer to a main road (c $0.2 \mathrm{~km}$ ).

The four rural sites were located in QZ, WQ, HM and SG counties. These are 51, 39, 51 and $25 \mathrm{~km}$ away from their nearest cities (Xingtai, Dezhou, Binzhou and Weifang, respectively) and have arable land coverages of about $75 \%$. Winter wheat, summer maize, cotton and greenhouse vegetables are the main crops in QZ, WQ and HM, while greenhouse vegetables are the main crops in SG. Ammonia emission intensities at the four rural sites can be ranked as high due to the large area of arable land and high $\mathrm{N}$ fertilizer application rates. The sites QZ, SG and SZ were about $2 \mathrm{~km}$ away from the main roads, while the distance of WQ and HM to the nearest main roads was more than $10 \mathrm{~km}$.

In the winter wheat/summer maize rotations, $\mathrm{N}$ fertilizer application rates are usually as high as 500-600 $\mathrm{kg} \mathrm{N}^{-1} \mathrm{yr}^{-1}$ (Ju et al., 2009). Nitrogen fertilizers are used as basal fertilizers at the beginning of October (for winter wheat) and in late June or at the beginning of July (for summer maize), and used as a topdressing in March or/and April (for winter wheat) and July and

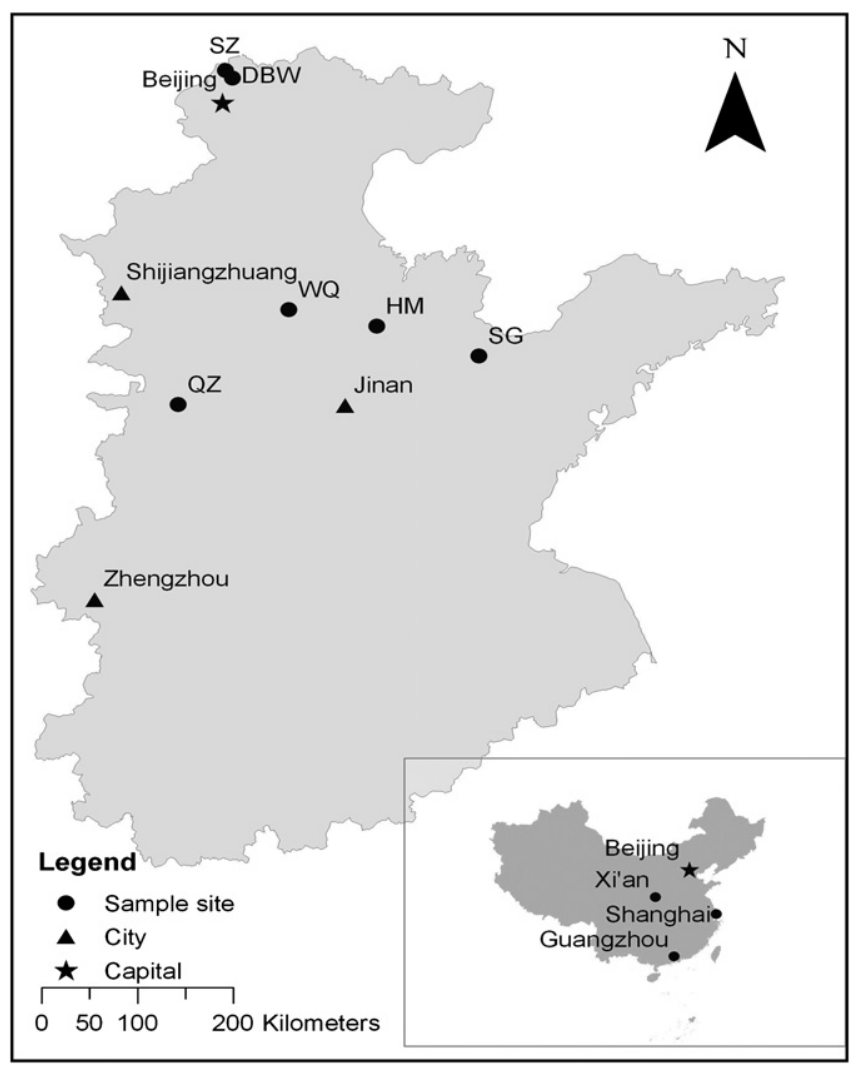

Fig. 1. Map of sampling sites in the North China Plain.

August (for Summer maize). For greenhouse vegetable production, double-cropping is typical without supplementary heating or illumination and total $\mathrm{N}$ fertilizer application rates are extremely high at $1000-2000 \mathrm{~kg} \mathrm{~N} \mathrm{ha}^{-1} \mathrm{yr}^{-1}$. Basal fertilizers are used in summer, while top-dressing fertilizers are applied in the other three seasons.

\subsection{Meteorological factors}

The climate of the North China Plain is sub-humid temperate. Annual average precipitation ranges from 400 to $700 \mathrm{~mm}$ with approximately $70 \%$ of the precipitation occurring in the summer (June to August). Highest relative humidity and lowest wind speed are often found in the summer, while lowest relative humidity and highest wind speed usually occur in spring and part of the winter. The meteorological data (air temperature, wind speed, wind direction, precipitation, and relative humidity) at SZ, WQ HM and SG were obtained from local meteorological bureaus, while those at DBW and QZ sites were recorded at weather stations in the fields not far from the sampling sites.

\subsection{Sampling methods and chemical analysis}

Sampling was conducted during August 2006 to September 2009. Two sampling strategies were used for different sampling sites. Ammonia and particulate matter concentrations were measured monthly at DBW, QZ and SZ (sampling strategy 1) and seasonally at WQ HM and SG. (sampling strategy 2). Detailed sampling and analytical methods are as follows.

\subsection{1. $\mathrm{NH}_{3}$}

$\mathrm{NH}_{3}$ concentrations were measured with Radiello ${ }^{\circledR}$ passive samplers (Aquaria, Italia). Three $\mathrm{NH}_{3}$ samplers per site for each 
Table 1

Mean $\mathrm{NH}_{3}, \mathrm{NO}_{2}, \mathrm{HNO}_{3}$ and $\mathrm{SO}_{2}$ concentrations at six sites in the NCP.

\begin{tabular}{|c|c|c|c|c|c|c|}
\hline Site & $\begin{array}{l}\text { Sampling } \\
\text { frequency }\end{array}$ & $\begin{array}{l}\mathrm{NH}_{3} \text { emission intensity } \\
\mathrm{kg} \mathrm{N} \mathrm{ha}^{-1} \mathrm{yr}^{-1}\end{array}$ & $\mathrm{NH}_{3} \mu \mathrm{g} \mathrm{m}^{-3}$ & $\mathrm{NO}_{2} \mu \mathrm{g} \mathrm{m}^{-3}$ & $\mathrm{HNO}_{3} \mu \mathrm{g} \mathrm{m}^{-3}$ & $\mathrm{SO}_{2} \mu \mathrm{g} \mathrm{m}^{-3}$ \\
\hline DBW & Monthly & 55.4 & $14.0 \pm 7.3$ & $71.2 \pm 21.8$ & $1.9^{\mathrm{a}}$ & $39.0^{c}$ \\
\hline $\mathrm{QZ}$ & Monthly & 85.8 & $16.2 \pm 10.3$ & $39.6 \pm 27.8$ & $2.3 \pm 1.9$ & $22.3 \pm 8.9$ \\
\hline SZ & Monthly & 46.2 & $9.4 \pm 6.3$ & $37.6 \pm 15.1$ & $1.9^{\mathrm{a}}$ & $39.0^{c}$ \\
\hline HM & Seasonally & 83.7 & $8.9 \pm 3.3$ & $17.7 \pm 11.8$ & n.d. ${ }^{\mathrm{b}}$ & $57.3^{d}$ \\
\hline SG & Seasonally & 79.9 & $24.2 \pm 20.9$ & $31.1 \pm 15.1$ & n.d. & $101.6^{\mathrm{d}}$ \\
\hline WQ & Seasonally & 76.0 & $21.0 \pm 22.2$ & $16.9 \pm 11.8$ & n.d. & $52.5^{\mathrm{d}}$ \\
\hline
\end{tabular}

a Cited from Wu et al. (2009).

b Not determined.

c Mean $\mathrm{SO}_{2}$ concentration in Beijing during 2007-2009 reported by BEPB (2010).

d $\mathrm{SO}_{2}$ concentrations at HM, SG and WQ were taken from the first half-year mean values for 2010 in nearby cities Jinan, Weifang and Shijiazhuang, respectively, which were reported by the Ministry of Environmental Protection of China (MEPC, 2010).

sampling period were exposed in a PVC shelter $(2 \mathrm{~m}$ above the ground), which protected the samplers from precipitation and direct sunlight. The $\mathrm{NH}_{3}$ concentrations were measured for a month by exposing the samplers for two weeks in the middle of each month during August 2006 to July 2007 at DBW and QZ, and from October 2007 to September 2009 by exposing the samplers for half a month at QZ and SZ. For the seasonal $\mathrm{NH}_{3}$ concentration measurements at WQ $\mathrm{HM}$ and SG, ammonia concentrations were measured once in each season (autumn, winter, spring and summer) by exposing the passive samplers for six days. After
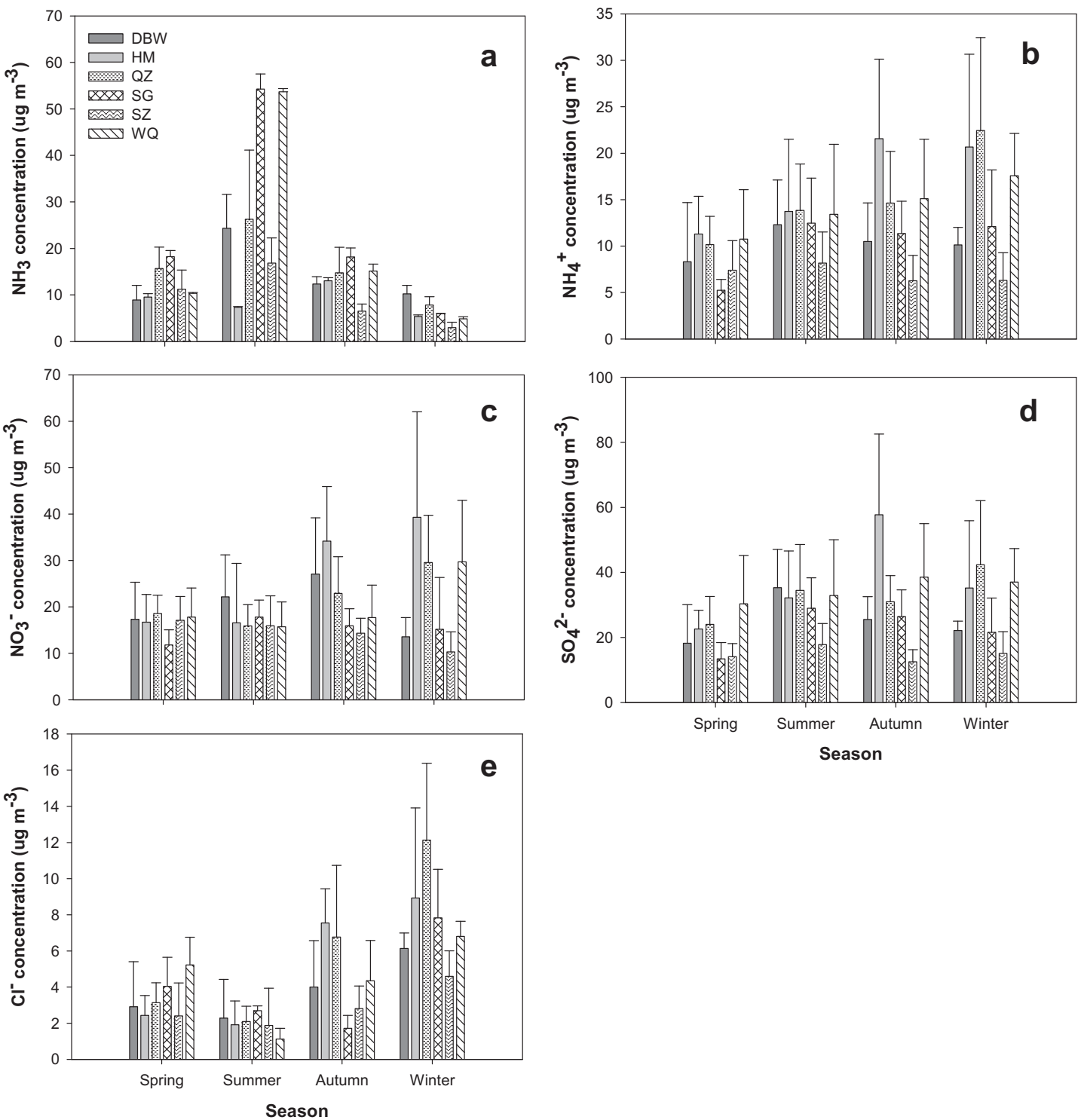

Fig. 2. Seasonal mean concentrations of $\mathrm{NH}_{3}$ (a), particulate $\mathrm{NH}_{4}{ }^{+}$(b), $\mathrm{NO}_{3}{ }^{-}$(c), $\mathrm{SO}_{4}{ }^{2-}$ (d) and $\mathrm{Cl}^{-}$(e) in $\mathrm{PM}_{10}$ across sites. Error bars mean the standard deviations. 
exposure, absorption cartridges of the passive samplers were put into airtight plastic tubes and kept in a refrigerator at $4{ }^{\circ} \mathrm{C}$ until chemical analysis, which was made within two months. The cartridges were extracted with $10 \mathrm{ml}$ high-purity water (18.2 M $\Omega$ ) for 2 min using a VORTEX type stirrer, and the $\mathrm{NH}_{4}{ }^{+}-\mathrm{N}$ in the extractant measured by a continuous flow analyzer (TRAACS 2000, Germany). Field blank measurements were made each month or each season at every site.

\subsubsection{Particulate matter}

A portable particulate sampler (frmOMNI, BGI Inc., USA) was used to sample $\mathrm{PM}_{10}$ and $\mathrm{PM}_{2.5}$ during August 2006 and August 2007. During this sampling period, five daily $\mathrm{PM}_{10}$ and five daily $\mathrm{PM}_{2.5}$ (three in first half of a month and two in the second half of a month) samples were collected at DBW and QZ in each month, while three daily $\mathrm{PM}_{10}$ and three daily $\mathrm{PM}_{2.5}$ samples were obtained at WQ HM and SG in each season (autumn, winter, spring and summer). High volume samplers (TH1000C, Tianhong Co., China) were used to sample $\mathrm{PM}_{10}$ during October 2007 to September 2009 at SZ and QZ. A 24-h PM 10 sample was obtained every other day except the days without electricity or when mechanical problems occurred. Detailed measurement and analysis methods for particulate matter and particulate dissolvable inorganic ions $\left(\mathrm{NO}_{3}{ }^{-}, \mathrm{SO}_{4}{ }^{2-}, \mathrm{Cl}^{-}, \mathrm{NH}_{4}{ }^{+}, \mathrm{K}^{+}, \mathrm{Ca}^{2+}, \mathrm{Mg}^{2+}\right.$ and $\mathrm{Na}^{+}$) were described by Shen et al. (2009). Briefly, concentrations of $\mathrm{PM}_{10}$ or $\mathrm{PM}_{2.5}$ were calculated according to weight differences between filters before and after sampling; while concentrations of particulate inorganic anions and cations were measured by ion chromatography (DX-120, Dionex, USA) and ICP-AES (Optima 3300DV, USA), respectively.

\section{Results and discussion}

\section{1. $\mathrm{NH}_{3}$ concentrations}

Mean $\mathrm{NH}_{3}$ concentrations across sampling sites are shown in Table 1. The mean $\mathrm{NH}_{3}$ concentrations were in the range $8.9-24.2 \mu \mathrm{g} \mathrm{m}^{-3}$, showing a positive correlation with $\mathrm{NH}_{3}$ emission intensity (46.2-85.8 $\mathrm{kg} \mathrm{N} \mathrm{ha}^{-1} \mathrm{yr}^{-1}$ ). The mean $\mathrm{NH}_{3}$ concentration was highest at $\mathrm{SG}$, which could be due to the large quantities of $\mathrm{NH}_{3}$ emission from greenhouse vegetable production in Shouguang County, where farmers use extremely high rates of $\mathrm{N}$ fertilizers (e.g., $1900 \mathrm{~kg} \mathrm{~N}^{-1}$ as chemical $\mathrm{N}$ fertilizer and an additional $1000 \mathrm{~kg} \mathrm{~N} \mathrm{ha}^{-1}$ as organic manure) in the field every year to obtain high yields. In comparison, the mean $\mathrm{NH}_{3}$ concentrations were $11-23 \mu \mathrm{g} \mathrm{m}^{-3}$ at sites with emission intensities in the range of 50-200 $\mathrm{kg} \mathrm{NH}_{3}-\mathrm{N} \mathrm{ha}^{-1} \mathrm{yr}^{-1}$ in the Netherlands (Buijsman et al., 1998). Unexpectedly, the mean $\mathrm{NH}_{3}$ concentration was lowest at $\mathrm{HM}\left(7.3 \mu \mathrm{g} \mathrm{m}^{-3}\right)$, a site with moderate $\mathrm{NH}_{3}$ emission intensity. As there were several heavy rainfall events at HM during the summer sampling, rainfall scavenging may have caused this. Lower $\mathrm{NH}_{3}$ concentration was also observed at SZ, which also had the lowest emission intensity among the six sampling sites. Though DBW has similar $\mathrm{NH}_{3}$ emissions to $\mathrm{SZ}$, the small distance $(200 \mathrm{~m})$ to the main road means that DBW was easily affected by $\mathrm{NH}_{3}$ emissions from cars and other vehicles with catalytic converters (Cape et al., 2004).

Owing to the high $\mathrm{NH}_{3}$ emission intensities, the $\mathrm{NH}_{3}$ concentrations at the sampling sites were higher than those measured at many agricultural sites in American, Asian, and European countries (e.g., Burkhardt et al., 1998; Edgerton et al., 2007; Hong et al., 2002; Horváth and Sutton, 1998; Walker et al., 2004 and references therein). Similar high $\mathrm{NH}_{3}$ concentration $\left(14.1 \mu \mathrm{g} \mathrm{m} \mathrm{m}^{-3}\right.$ ) to those measured in this study was reported at an agricultural site with fruit production in the Guanzhong Plain in Northwest China (Cao et al., 2009).

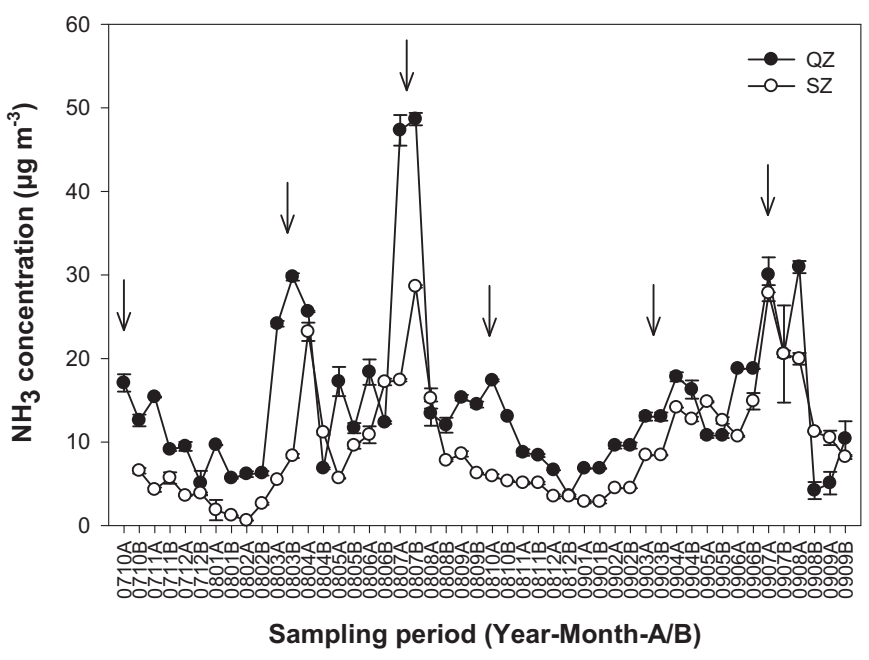

Fig. 3. Half-monthly mean $\mathrm{NH}_{3}$ concentrations measured at Quzhou (QZ) and Shangzhuang (SZ) during October 2007 and September 2009 (A-the first half of a month, B-the second half of a month). Downward arrows represent $\mathrm{N}$ fertilizer applications during the sampling periods.

The ammonia concentrations at the six sampling sites showed distinct seasonal variations (Fig. 2). Averaged $\mathrm{NH}_{3}$ concentrations across the sites were $12.3 \pm 3.8,30.5 \pm 19.4,13.3 \pm 3.9$ and $6.2 \pm 2.5 \mu \mathrm{g} \mathrm{m}^{-3}$ in spring, summer, autumn and winter, respectively. Ammonia concentrations in summer were 3.9, 1.5 and 1.3 times higher than those in winter, spring and autumn, respectively. Nitrogen fertilizer applications have a major impact on atmospheric $\mathrm{NH}_{3}$ concentrations. As shown in Fig. 3, $\mathrm{NH}_{3}$ concentrations increased sharply after $\mathrm{N}$ fertilizer application in October and March or April for winter wheat, and in July or August for summer maize at QZ and SZ. This is most probably due to $\mathrm{NH}_{3}$ volatilization from urea, the most common $\mathrm{N}$ fertilizer in China. As reported by Ju et al. (2009), due to the very large amounts of $\mathrm{N}$ fertilizer applied, $\mathrm{N}$ loss from $\mathrm{NH}_{3}$ volatilization in the NCP accounted for 19 and $25 \%$ of the applied $\mathrm{N}$ fertilizer for winter wheat and summer maize, respectively. As $\mathrm{NH}_{3}$ volatilization is promoted by higher temperatures, atmospheric $\mathrm{NH}_{3}$ concentration may be indirectly affected by air temperature. As shown in Fig. 4, $\mathrm{NH}_{3}$ concentrations increased exponentially with the increase in air temperature at the sampling sites, which was consistent with the findings of Yamamoto et al. (1995) and Robarge et al. (2002).

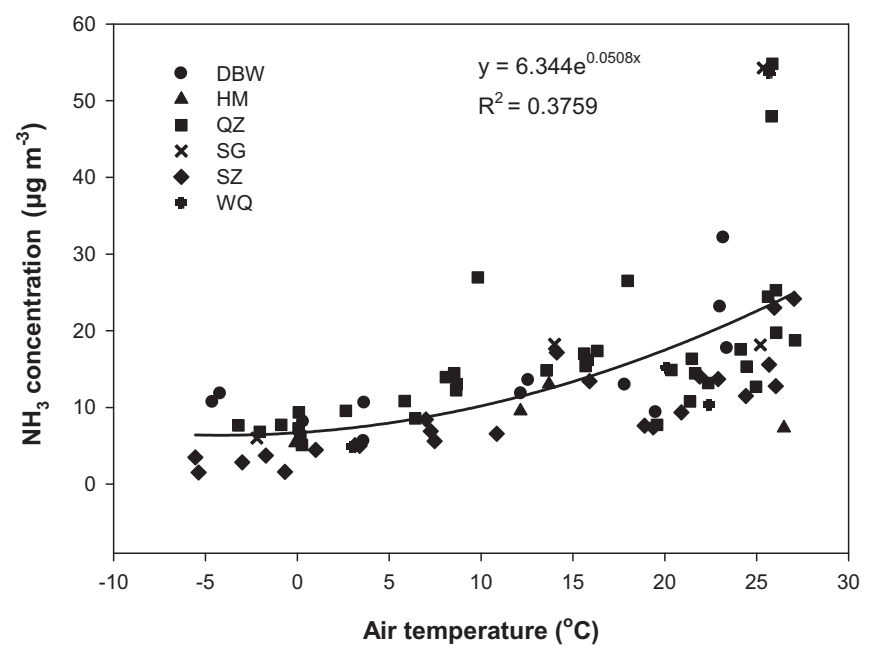

Fig. 4. Correlation between air temperature and $\mathrm{NH}_{3}$ concentration across the sites. 
Table 2

Mean mass concentrations of $\mathrm{PM}_{10}, \mathrm{PM}_{2.5}$, and ions $\left(\mathrm{NH}_{4}{ }^{+}, \mathrm{NO}_{3}{ }^{-}, \mathrm{SO}_{4}{ }^{2-}, \mathrm{Cl}^{-}\right)$in $\mathrm{PM}_{10}$ and $\mathrm{PM}_{2.5}$. Data in the parenthesis are standard deviations.

\begin{tabular}{|c|c|c|c|c|c|c|c|c|c|c|c|c|c|c|c|c|}
\hline \multirow[t]{2}{*}{ Site } & \multirow[t]{2}{*}{ No. } & \multicolumn{3}{|l|}{ PM } & \multicolumn{3}{|l|}{$\mathrm{NH}_{4}^{+}$} & \multicolumn{3}{|l|}{$\mathrm{NO}_{3}{ }^{-}$} & \multicolumn{3}{|l|}{$\mathrm{SO}_{4}{ }^{2-}$} & \multicolumn{3}{|l|}{$\underline{\mathrm{Cl}^{-}}$} \\
\hline & & $\mathrm{PM}_{10}$ & $\mathrm{PM}_{2.5}$ & Ratio & $\mathrm{PM}_{10}$ & $\mathrm{PM}_{2.5}$ & Ratio & $\mathrm{PM}_{10}$ & $\mathrm{PM}_{2.5}$ & Ratio & $\mathrm{PM}_{10}$ & $\mathrm{PM}_{2.5}$ & Ratio & $\mathrm{PM}_{10}$ & $\mathrm{PM}_{2.5}$ & Ratio \\
\hline DBW & 54 & $204.8(102.0)$ & $136.2(67.3)$ & 0.66 & $10.0(7.9)$ & $8.8(6.7)$ & 0.88 & $19.9(16.3)$ & $15.1(11.4)$ & 0.76 & $25.5(20.1)$ & $22.4(16.2)$ & 0.88 & $3.7(3.3)$ & $2.8(2.5)$ & 0.75 \\
\hline $\mathrm{QZ1}^{\mathrm{a}}$ & 54 & $223.9(156.1)$ & 159.6 (93.8) & 0.71 & $16.1(13.6)$ & $15.5(12.4)$ & 0.96 & $22.3(18.2)$ & $19.1(13.2)$ & 0.86 & $36.1(24.3)$ & $31.2(21.6)$ & 0.87 & $7.0(7.5)$ & $6.0(7.4)$ & 0.86 \\
\hline HM & 12 & $195.4(97.4)$ & $148.6(88.2)$ & 0.76 & $16.8(8.8)$ & $13.0(8.9)$ & 0.77 & $26.7(17.3)$ & $18.1(17.0)$ & 0.68 & $36.9(20.7)$ & $30.4(19.6)$ & 0.82 & $5.2(4.1)$ & $3.7(4.2)$ & 0.71 \\
\hline SG & 11 & $153.9(66.3)$ & $111.2(37.2)$ & 0.72 & $9.9(4.7)$ & $9.7(4.2)$ & 0.98 & $12.8(5.8)$ & $11.2(4.6)$ & 0.88 & $21.5(10.3)$ & $21.7(10.3)$ & 1.00 & $4.6(2.9)$ & $4.3(2.9)$ & 0.94 \\
\hline WQ & 12 & $171.7(84.2)$ & $125.3(61.8)$ & 0.73 & $14.5(6.8)$ & $13.1(5.4)$ & 0.90 & $21.7(11.1)$ & $18.0(9.3)$ & 0.83 & 34.7 (14.9) & $29.0(14.8)$ & 0.83 & $4.4(2.6)$ & $3.1(2.3)$ & 0.70 \\
\hline $\mathrm{QZ2}^{\mathrm{a}}$ & 288 & $171.1(111.7)$ & n.d. & n.d. ${ }^{b}$ & $12.9(12.2)$ & n.d. & n.d. & $19.9(14.6)$ & n.d. & n.d. & $29.1(23.1)$ & n.d. & n.d. & $5.5(5.4)$ & n.d. & n.d. \\
\hline SZ & 298 & $138.7(111.6)$ & n.d. & n.d. & $6.6(7.7)$ & n.d. & n.d. & 13.7 (13.7) & n.d. & n.d. & $15.9(23.7)$ & n.d. & n.d. & $2.0(3.3)$ & n.d. & n.d. \\
\hline
\end{tabular}

a QZ1 and QZ2 mean concentrations of $\mathrm{PM}_{10}, \mathrm{PM}_{2.5}$ and ions at Quzhou were measured during period 1 (from August 2006 to July 2007 ) and period 2 (from October 2007 to September 2009), respectively.

b Not determined.

\subsection{Particulate $\mathrm{NH}_{4}{ }^{+}, \mathrm{NO}_{3}{ }^{-}, \mathrm{SO}_{4}{ }^{2-}$ and $\mathrm{Cl}^{-}$concentrations}

Table 2 shows mass concentrations of $\mathrm{PM}_{10}, \mathrm{PM}_{2.5}$, and inorganic ions (particulate $\mathrm{NH}_{4}{ }^{+}, \mathrm{NO}_{3}{ }^{-}, \mathrm{SO}_{4}{ }^{2-}$ and $\mathrm{Cl}^{-}$) in $\mathrm{PM}_{10}$ and $\mathrm{PM}_{2.5}$ at the six sites. The mean concentrations of particulate $\mathrm{NH}_{4}{ }^{+}$in $\mathrm{PM}_{10}$ ranged from 6.6 to $16.8 \mu \mathrm{g} \mathrm{m}^{-3}$, while those of $\mathrm{PM}_{2.5}$ ranged from 8.8 to $15.5 \mu \mathrm{g} \mathrm{m}^{-3}$ (no data for $\mathrm{PM}_{2.5}$ at SZ). The concentrations of particulate $\mathrm{NH}_{4}{ }^{+}$in $\mathrm{PM}_{2.5}$ accounted for $77-98 \%$ of $\mathrm{PM}_{10}$ across the sampling sites (Table 2), indicating that most of the $\mathrm{NH}_{4}{ }^{+}$particles were in the fine fraction. In general, $\mathrm{NH}_{4}{ }^{+}$concentrations increased with the increase of $\mathrm{NH}_{3}$ emission intensities, with higher concentrations at rural sites than at suburban sites. The seasonal trends in $\mathrm{NH}_{4}{ }^{+}$concentrations were different from those of $\mathrm{NH}_{3}$. As shown in Fig. 2, $\mathrm{NH}_{4}{ }^{+}$concentrations were higher in summer at suburban sites, but higher in autumn and winter at rural sites. This difference may reflect the influences of primary air pollutants (here taken to be $\mathrm{NH}_{3}, \mathrm{NO}_{\mathrm{x}}$ and $\mathrm{SO}_{2}$ ) on the formation of secondary ammonium particles (e.g., $\left(\mathrm{NH}_{4}\right)_{2} \mathrm{SO}_{4}, \mathrm{NH}_{4} \mathrm{HSO}_{4}, \mathrm{NH}_{4} \mathrm{NO}_{3}$ ). In other words, the high $\mathrm{NO}_{\mathrm{x}}$ and $\mathrm{SO}_{2}$ concentrations and relative low $\mathrm{NH}_{3}$ concentrations at the suburban sites may make the $\mathrm{NH}_{3}$ concentration a restricting factor in secondary ammonium particle formation, while the high $\mathrm{NH}_{3}$ concentrations and relatively low $\mathrm{NO}_{\mathrm{x}}$ and $\mathrm{SO}_{2}$ concentrations at the rural sites may make the $\mathrm{NO}_{\mathrm{x}}$ and $\mathrm{SO}_{2}$ concentrations the restricting factors there. Therefore, because $\mathrm{NH}_{3}$ concentrations were highest in summer at the suburban sites (Fig. 2), and $\mathrm{NO}_{\mathrm{x}}$ and $\mathrm{SO}_{2}$ concentrations highest in winter at the rural sites (Meng et al., 2008; Shen et al., 2009), particulate $\mathrm{NH}_{4}{ }^{+}$concentrations were also highest in summer and winter at the suburban and rural sites, respectively. Similar to $\mathrm{NH}_{3}$ concentrations, particulate $\mathrm{NH}_{4}{ }^{+}$concentrations in this study were much higher than those measured at agricultural sites worldwide (Hong et al., 2002; Horváth and Sutton, 1998; Walker et al., 2004), while particulate $\mathrm{NH}_{4}^{+}$concentrations at the suburban sites in Beijing were comparable with those reported at other urban sites in Beijing (He et al., 2001; Wang et al., 2005).

Similar to particulate $\mathrm{NH}_{4}{ }^{+}$, concentrations of particulate $\mathrm{NO}_{3}{ }^{-}$, $\mathrm{SO}_{4}{ }^{2-}$ and $\mathrm{Cl}^{-}$were also very high at the sites (Table 2 and Fig. 2). For example, mean concentrations of particulate $\mathrm{NO}_{3}{ }^{-}$and $\mathrm{SO}_{4}{ }^{2-}$ in $\mathrm{PM}_{10}$ were as high as $12.8-26.7 \mu \mathrm{g} \mathrm{m}^{-3}$ and $15.9-36.9 \mu \mathrm{g} \mathrm{m}^{-3}$, respectively. The concentrations of these three ions were also much higher than those measured in other regions (Gietl et al., 2008; Hong et al., 2002; Walker et al., 2004), but were comparable with those measured in urban sites with serious pollution problems in China (He et al., 2001; Wang et al., 2005). The masses of particulate $\mathrm{NO}_{3}{ }^{-}, \mathrm{SO}_{4}{ }^{2-}$ and $\mathrm{Cl}^{-}$in $\mathrm{PM}_{2.5}$ accounted for 68 to almost $100 \%$ of those in $\mathrm{PM}_{10}$, indicating that these ions were also comprised of mostly fine particles. The concentrations of particulate $\mathrm{NO}_{3}{ }^{-}, \mathrm{SO}_{4}{ }^{2-}$ and $\mathrm{Cl}^{-}$showed different seasonal variations at the sites (Fig. 2). The seasonal variation of particulate $\mathrm{NO}_{3}{ }^{-}$was similar to that of particulate $\mathrm{NH}_{4}{ }^{+}$, with higher concentrations in summer at suburban sites and in winter at rural sites. Concentrations of particulate $\mathrm{SO}_{4}{ }^{2-}$ were highest in summer and lowest in spring, indicating that $\mathrm{SO}_{2}$ emission intensity and temperature have important influences on the formation of sulphate (Khoder, 2002). Particulate $\mathrm{Cl}^{-}$concentrations across the sites were highest in winter and lowest in summer, which corresponds to coal consumption patterns.

\subsection{Correlations between particulate $\mathrm{NH}_{4}{ }^{+}$and $\mathrm{SO}_{4}{ }^{2-}$, $\mathrm{NO}_{3}{ }^{-}$and $\mathrm{Cl}^{-}$}

Pearson correlation coefficients between molar concentrations of particulate $\mathrm{NH}_{4}{ }^{+}$and $\mathrm{NO}_{3}{ }^{-}, \mathrm{SO}_{4}{ }^{2-}$ and $\mathrm{Cl}^{-}$in $\mathrm{PM}_{10}$ and $\mathrm{PM}_{2.5}$ are shown in Table 3 . There were significant positive correlations between $\mathrm{NH}_{4}^{+}$and $\mathrm{NO}_{3}{ }^{-}$as well as $\mathrm{NH}_{4}^{+}$and $\mathrm{SO}_{4}{ }^{2-}$ at the six

Table 3

Correlation coefficients $\left(R^{2}\right)$ between molar concentrations of $\mathrm{NH}_{4}{ }^{+}$and $\mathrm{NO}_{3}{ }^{-}, \mathrm{SO}_{4}{ }^{2-}$ and $\mathrm{Cl}^{-}$in $\mathrm{PM}_{10}$ and $\mathrm{PM}_{2.5}$.

\begin{tabular}{|c|c|c|c|c|c|c|c|c|c|c|c|}
\hline \multirow[t]{2}{*}{ Site } & \multirow[t]{2}{*}{ No. } & \multicolumn{2}{|c|}{$\mathrm{NO}_{3}{ }^{-}$vs $\mathrm{NH}_{4}^{+}$} & \multicolumn{2}{|c|}{$\mathrm{SO}_{4}{ }^{2-} v s \mathrm{NH}_{4}^{+}$} & \multicolumn{2}{|c|}{$\mathrm{Cl}^{-}$vs $\mathrm{NH}_{4}^{+}$} & \multicolumn{2}{|c|}{$\begin{array}{l}\left(\mathrm{NO}_{3}^{-}+\mathrm{SO}_{4}^{2-}\right) \\
v s \mathrm{NH}_{4}^{+}\end{array}$} & \multicolumn{2}{|c|}{$\begin{array}{l}\left(\mathrm{NO}_{3}^{-}+\mathrm{SO}_{4}^{2-}+\mathrm{Cl}^{-}\right) \\
\text {vs } \mathrm{NH}_{4}^{+}\end{array}$} \\
\hline & & $\mathrm{PM}_{10}$ & $\mathrm{PM}_{2.5}$ & $\mathrm{PM}_{10}$ & $\mathrm{PM}_{2.5}$ & $\mathrm{PM}_{10}$ & $\mathrm{PM}_{2.5}$ & $\mathrm{PM}_{10}$ & $\mathrm{PM}_{2.5}$ & $\mathrm{PM}_{10}$ & $\mathrm{PM}_{2.5}$ \\
\hline DBW & 54 & $0.768^{* *}$ & $0.718^{* *}$ & $0.777^{* *}$ & $0.796^{* *}$ & $0.279^{* *}$ & $0.128^{*}$ & $0.903^{* *}$ & $0.893^{* *}$ & $0.897^{* *}$ & $0.874^{* *}$ \\
\hline $\mathrm{QZ1}^{\mathrm{a}}$ & 54 & $0.884^{* *}$ & $0.850^{* *}$ & $0.796^{* *}$ & $0.776^{* *}$ & $0.376^{* *}$ & $0.509^{* *}$ & $0.954^{* *}$ & $0.921^{* *}$ & $0.919^{* *}$ & $0.928^{* *}$ \\
\hline HM & 12 & $0.845^{* *}$ & $0.801^{* *}$ & $0.806^{* *}$ & $0.765^{* *}$ & $0.414^{*}$ & $0.681^{* *}$ & $0.946^{* *}$ & $0.942^{* *}$ & $0.895^{* *}$ & $0.935^{* *}$ \\
\hline SG & 11 & $0.731^{*}$ & $0.706^{*}$ & $0.758^{* *}$ & $0.893^{* *}$ & 0.064 & 0.046 & $0.814^{* *}$ & $0.848^{* *}$ & $0.840^{* *}$ & $0.841^{* *}$ \\
\hline WQ & 12 & $0.441^{*}$ & $0.396^{*}$ & $0.799^{* *}$ & $0.874^{* *}$ & 0.096 & 0.200 & $0.825^{* *}$ & $0.848^{* *}$ & $0.749 * *$ & $0.773 * *$ \\
\hline $\mathrm{QZ2}^{\mathrm{a}}$ & 288 & $0.783^{* *}$ & n.d. ${ }^{b}$ & $0.746^{* *}$ & n.d. & $0.355^{* *}$ & n.d. & $0.860^{* *}$ & n.d. & $0.843^{* *}$ & n.d. \\
\hline SZ & 298 & $0.823^{* *}$ & n.d. & $0.788^{* *}$ & n.d. & $0.228^{* *}$ & n.d. & $0.890^{* *}$ & n.d. & $0.866^{* *}$ & n.d. \\
\hline
\end{tabular}

** significant at 0.01 level, *significant at 0.05 level.

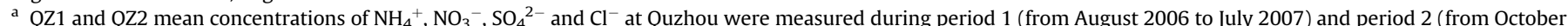
2007 to September 2009), respectively.

b Not determined. 
Table 4

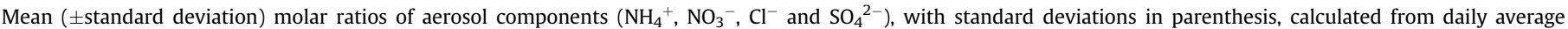
concentrations in $\mathrm{PM}_{2.5}$ and $\mathrm{PM}_{10}$ at the sampling sites.

\begin{tabular}{|c|c|c|c|c|c|c|}
\hline \multirow[t]{2}{*}{ Site } & \multicolumn{3}{|l|}{$\mathrm{PM}_{2.5}$} & \multicolumn{3}{|l|}{$\mathrm{PM}_{10}$} \\
\hline & $\mathrm{NO}_{3}{ }^{-} / \mathrm{NH}_{4}{ }^{+}$ & $\mathrm{Cl}^{-} / \mathrm{NH}_{4}^{+}$ & $\mathrm{NH}_{4}^{+} / \mathrm{SO}_{4}^{2-\mathrm{b}}$ & $\mathrm{NO}_{3}{ }^{-} / \mathrm{NH}_{4}{ }^{+}$ & $\mathrm{Cl}^{-} / \mathrm{NH}_{4}^{+}$ & $\mathrm{NH}_{4}^{+} / \mathrm{SO}_{4}{ }^{2-}$ \\
\hline DBW & $0.49 \pm 0.17$ & $0.16 \pm 0.15$ & $1.13 \pm 0.66$ & $0.58 \pm 0.21$ & $0.19 \pm 0.19$ & $0.92 \pm 0.66$ \\
\hline $\mathrm{QZ1}^{\mathrm{a}}$ & $0.39 \pm 0.15$ & $0.17 \pm 0.11$ & $1.58 \pm 0.60$ & $0.41 \pm 0.15$ & $0.20 \pm 0.15$ & $1.36 \pm 0.49$ \\
\hline $\mathrm{HM}$ & $0.38 \pm 0.18$ & $0.14 \pm 0.12$ & $1.52 \pm 0.88$ & $0.44 \pm 0.13$ & $0.16 \pm 0.10$ & $1.34 \pm 0.29$ \\
\hline SG & $0.35 \pm 0.10$ & $0.28 \pm 0.21$ & $1.61 \pm 0.52$ & $0.43 \pm 0.14$ & $0.24 \pm 0.17$ & $1.46 \pm 0.62$ \\
\hline WQ & $0.40 \pm 0.11$ & $0.14 \pm 0.12$ & $1.65 \pm 0.84$ & $0.47 \pm 0.16$ & $0.17 \pm 0.13$ & $1.16 \pm 0.37$ \\
\hline $\mathrm{QZ2}^{\mathrm{a}}$ & n.d. ${ }^{c}$ & n.d. & n.d. & $0.47 \pm 0.15$ & $0.20 \pm 0.15$ & $1.35 \pm 0.82$ \\
\hline SZ & n.d. & n.d. & n.d. & $0.55 \pm 0.23$ & $0.19 \pm 0.16$ & $1.18 \pm 0.84$ \\
\hline
\end{tabular}

${ }^{\text {a }}$ QZ1 and QZ2 mean concentrations of $\mathrm{NH}_{4}{ }^{+}, \mathrm{NO}_{3}{ }^{-}, \mathrm{SO}_{4}{ }^{2-}$ and $\mathrm{Cl}^{-}$at Quzhou were measured during period 1 (from August 2006 to July 2007 ) and period 2 (from October 2007 to September 2009), respectively.

${ }^{\mathrm{b}} \mathrm{NH}_{4}^{+}$represents the molar concentration of $\mathrm{NH}_{4}^{+}$that is not associated with $\mathrm{NO}_{3}^{-}\left(\mathrm{NH}_{4}^{+}-\mathrm{NO}_{3}{ }^{-}\right)$.

c Not determined.

sampling sites, and the positive correlations between $\mathrm{NH}_{4}{ }^{+}$and $\mathrm{Cl}^{-}$ were also significant at four sites (DBW, HM, QZ and SZ). However, the correlation coefficients between $\mathrm{NH}_{4}{ }^{+}$and the sum of $\mathrm{NO}_{3}{ }^{-}$and $\mathrm{SO}_{4}{ }^{2-}$ at most of the sampling sites were higher than those between $\mathrm{NH}_{4}{ }^{+}$and the sum of $\mathrm{NO}_{3}{ }^{-}, \mathrm{SO}_{4}{ }^{2-}$ and $\mathrm{Cl}^{-}$. This indicates that particulate $\mathrm{NH}_{4}{ }^{+}$was probably mainly associated with particulate $\mathrm{NO}_{3}{ }^{-}$and $\mathrm{SO}_{4}{ }^{2-}$, and so particulates are likely to be $\mathrm{NH}_{4} \mathrm{NO}_{3},\left(\mathrm{NH}_{4}\right)_{2} \mathrm{SO}_{4}$ and/or $\mathrm{NH}_{4} \mathrm{HSO}_{4}$, which are the secondary products of high concentrations of $\mathrm{NH}_{3}, \mathrm{SO}_{2}$ and $\mathrm{NO}_{\mathrm{x}}$ measured (Table 1).

Further analysis showed that molar ratios of $\mathrm{NO}_{3}{ }^{-} / \mathrm{NH}_{4}{ }^{+}$and $\left(\mathrm{NH}_{4}{ }^{+}-\mathrm{NO}_{3}{ }^{-}\right) / \mathrm{SO}_{4}{ }^{2-}$ were from 0.41 to 0.59 and from 0.95 to 1.43 respectively, across the sites (Table 4). Molar ratios of $\mathrm{NO}_{3}{ }^{-} / \mathrm{NH}_{4}{ }^{+}$ were higher at the suburban sites (DBW and SZ) than at the rural sites (QZ, WQ HM and SG), corresponding to relatively higher $\mathrm{NO}_{2}$ concentrations and lower $\mathrm{NH}_{3}$ concentrations in the suburban sites compared with the rural sites (Table 1 ). Molar ratios of $\left(\mathrm{NH}_{4}^{+}-\right.$ $\left.\mathrm{NO}_{3}{ }^{-}\right) / \mathrm{SO}_{4}{ }^{2-}$ were close to 1.0 at the suburban sites, while they were larger than 1.0 at the rural sites. This indicates that ammonium particles mainly existed as $\mathrm{NH}_{4} \mathrm{NO}_{3}$ and $\mathrm{NH}_{4} \mathrm{HSO}_{4}$ at the suburban sites and $\mathrm{NH}_{4} \mathrm{NO}_{3}, \mathrm{NH}_{4} \mathrm{HSO}_{4}$ and $\left(\mathrm{NH}_{4}\right)_{2} \mathrm{SO}_{4}$ at the rural sites (Walker et al., 2004).

The mean concentrations of secondary inorganic particles (here referring to the sum of $\mathrm{NH}_{4}{ }^{+}, \mathrm{SO}_{4}{ }^{2-}$ and $\mathrm{NO}_{3}{ }^{-}$) across the sites were as high as $36.1-80.4 \mu \mathrm{g} \mathrm{m}^{-3}$ (with an average of $59.6 \mu \mathrm{g} \mathrm{m}^{-3}$ ), which accounted for $24.2-41.2 \%$ (with an average of 33.5\%) of the $\mathrm{PM}_{10}$ concentrations (Table 1 ). The Chinese Ministry of Environmental Protection had established an ambient standard for $\mathrm{PM}_{10}$ of $100 \mu \mathrm{g} \mathrm{m}^{-3}$ on an annual average basis. The concentration of secondary inorganic particles at our sampling sites sometimes reached $60 \%$ of this standard. Furthermore, the concentration of secondary particles exceeded the standard set by the US Environmental Protection Agency for $\mathrm{PM}_{10}\left(50 \mu \mathrm{g} \mathrm{m}^{-3}\right.$ on an annual average basis) at most of the sampling sites. Therefore, a reduction of the concentration of secondary inorganic particles should be a target for the NCP to improve air quality.

\subsection{Ratios of $\mathrm{NH}_{3}$ to $\mathrm{NH}_{x}$}

The ratio of $\mathrm{NH}_{3}$ to $\mathrm{NH}_{\mathrm{X}}$ had been used to identify the source of $\mathrm{NH}_{\mathrm{X}}$ and the relative contribution of $\mathrm{NH}_{3}$ and $\mathrm{NH}_{4}^{+}$to $\mathrm{NH}_{\mathrm{X}}$ deposition (Walker et al., 2004). When the value is higher than 0.5 , it signifies that $\mathrm{NH}_{\mathrm{x}}$ is mainly from local $\mathrm{NH}_{3}$ sources and dry deposition of $\mathrm{NH}_{3}$ contributes most to $\mathrm{NH}_{\mathrm{x}}$ deposition. $\mathrm{NH}_{4}{ }^{+}$in this system derives from long-range transport and local formation. In contrast, when the ratio of $\mathrm{NH}_{3}$ to $\mathrm{NH}_{\mathrm{x}}$ is less than 0.5 , it indicates that atmospheric $\mathrm{NH}_{\mathrm{x}}$ is strongly affected by long-range transport of $\mathrm{pNH}_{4}{ }^{+}$and $\mathrm{NH}_{\mathrm{x}}$ deposition is dominated by dry and wet depositions of $\mathrm{NH}_{4}{ }^{+}$. Fig. 5 shows the seasonal ratios of $\mathrm{NH}_{3}$ to $\mathrm{NH}_{\mathrm{x}}$ across the sites. The ratios for most of the sites were higher than 0.5 in spring, summer and autumn, while lower than 0.5 in winter with only a few exceptions at HM and DBW (Fig. 5). This suggests that $\mathrm{NH}_{\mathrm{x}}$ was strongly influenced by local sources in spring, summer and autumn, while it was mainly affected by long-range transport in winter. It also can be inferred that $\mathrm{NH}_{3}$ dry deposition could contribute a large part of the $\mathrm{NH}_{\mathrm{x}}$ deposition in spring, summer and autumn, but a small part in winter across all the sites. Higher values for the ratio of $\mathrm{NH}_{3}$ to $\mathrm{NH}_{\mathrm{x}}$ at DBW in winter may be caused by $\mathrm{NH}_{3}$ emitted from vehicles near the sampling sites as $\mathrm{NH}_{3}$ emission from soils and plants was suppressed due to very cold weather. Lower values at $\mathrm{HM}$ in summer were likely caused by the under-estimation of $\mathrm{NH}_{3}$ concentrations because of the heavy rainfall, as discussed earlier.

\subsection{Emission, transport, transformation and deposition of $\mathrm{NH}_{3}$ in the NCP}

Using the monitored and published data, we initially estimated the emission, transport, transformation and deposition of $\mathrm{NH}_{3}$ in the NCP (Fig. 6). We assumed that the main source of $\mathrm{NH}_{3}$ emission in the cropland region is $\mathrm{NH}_{3}$ volatilization from $\mathrm{N}$ fertilizer, which was $1.62 \mathrm{Mt} \mathrm{NH}_{3}-\mathrm{N} \mathrm{yr}^{-1}$ in 2004 as reported by Zhang et al. (2010). When dividing the emission amount by the area of the NCP (about $320,000 \mathrm{~km}^{2}$ ), we obtained the averaged $\mathrm{NH}_{3}$ emission intensity from $\mathrm{N}$ fertilizer in the $\mathrm{NCP}$ of $51.7 \mathrm{~kg} \mathrm{NH}_{3}-\mathrm{N} \mathrm{yr}^{-1}$. As it is hard to

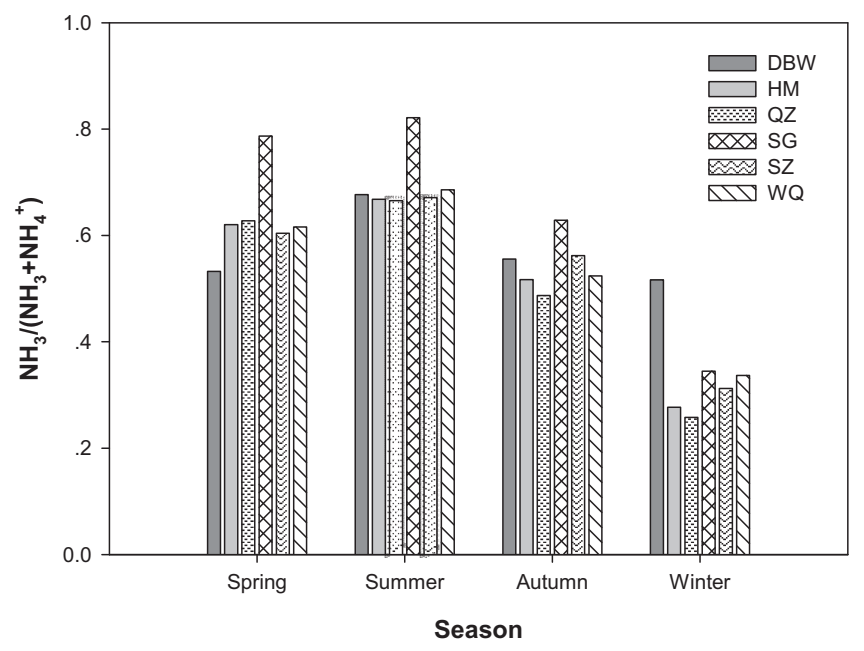

Fig. 5. Seasonal molar ratios of $\mathrm{NH}_{3}$ to $\mathrm{NH}_{3}+\mathrm{NH}_{4}^{+}$at the sites. 


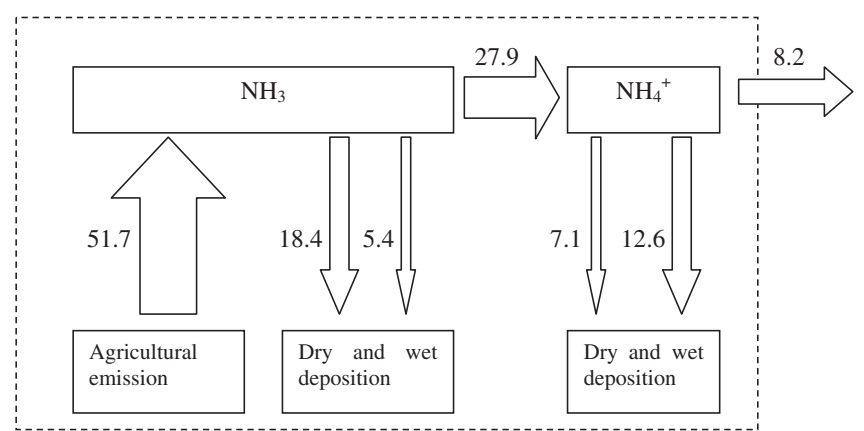

Fig. 6. An approximation of $\mathrm{NH}_{\mathrm{x}}$ emission, transport, transformation and deposition in the cropland regions of the NCP (unit: $\mathrm{kg} \mathrm{N}^{-1} \mathrm{yr}^{-1}$ ). $\mathrm{NH}_{3}$ emission intensity was obtained from Zhang et al. (2010). $\mathrm{NH}_{\mathrm{x}}$ wet deposition was obtained from Zhang et al. (2008), and the ratio of wet deposition of $\mathrm{NH}_{3}$ to $\mathrm{NH}_{\mathrm{x}}$ was taken to be 0.3 , as suggested by Asman (2001). The dry depositions of $\mathrm{NH}_{3}$ and $\mathrm{NH}_{4}$ were estimated using the simplified inferential method (Shen et al., 2009).

measure dry deposition of $\mathrm{NH}_{3}$ and particulate $\mathrm{NH}_{4}{ }^{+}$directly using the micrometeorological methods, the dry deposition rates in this study were calculated from the products of measured $\mathrm{NH}_{3}$ and $\mathrm{NH}_{4}{ }^{+}$concentrations and literature-based mean dry deposition velocities of $\mathrm{NH}_{3}\left(0.74 \mathrm{~cm} \mathrm{~s}^{-1}\right)$ and $\mathrm{NH}_{4}^{+}\left(0.24 \mathrm{~cm} \mathrm{~s}^{-1}\right)$ in agricultural regions (Hanson and Lindberg, 1991). For $\mathrm{NH}_{3}$, the compensation point ( $5 \mu \mathrm{g} \mathrm{N} \mathrm{m}^{-3}$ as an empirical value in croplands (Denmead et al., 2008)) was subtracted from the mean $\mathrm{NH}_{3}$ concentration when calculating dry deposition. The calculated mean $\mathrm{NH}_{3}$ and $\mathrm{NH}_{4}{ }^{+}$dry depositions (18.4 and $7.1 \mathrm{~kg} \mathrm{~N} \mathrm{ha}^{-1} \mathrm{yr}^{-1}$, respectively) at the sites in this study were used to represent the approximate mean values in the NCP. For wet deposition, the mean value of $\mathrm{NH}_{\mathrm{x}}$ wet deposition during 2004-2005 in the $\mathrm{NCP}(18.0 \mathrm{~kg}$ $\mathrm{N} \mathrm{ha}^{-1} \mathrm{yr}^{-1}$ ) as given by Zhang et al. (2008) was used. As there was no discrimination between wet deposition of $\mathrm{NH}_{3}$ and $\mathrm{NH}_{4}^{+}$by Zhang et al. (2008), here we assumed $\mathrm{NH}_{3}$ wet deposition accounts for $30 \%$ of $\mathrm{NH}_{\mathrm{x}}$ deposition as suggested by Asman (2001). As $\mathrm{NH}_{3}$ has a low residential time (several hours to 5 days) in the atmosphere, we assumed the emitted $\mathrm{NH}_{3}$ will be completely transformed to $\mathrm{NH}_{4}{ }^{+}$except for that deposited as dry and wet deposition. The calculated amount of $\mathrm{NH}_{3}$ transformed was $27.9 \mathrm{~kg}$ $\mathrm{N} \mathrm{ha}{ }^{-1} \mathrm{yr}^{-1}$, accounting for $54.0 \%$ of the emitted $\mathrm{NH}_{3}$. As particulate $\mathrm{NH}_{4}{ }^{+}$has a longer residential time, after any dry and wet deposition it can be transported long-distances. Here we estimated that about $8.2 \mathrm{~kg} \mathrm{NH}_{4}^{+}-\mathrm{N} \mathrm{ha}^{-1} \mathrm{yr}^{-1}$ or $0.26 \mathrm{Mt} \mathrm{yr}^{-1}$ in total would be transported from the NCP to surrounding terrestrial and marine ecosystems. This may cause secondary aerosol pollution in other regions and negative ecological impacts on natural and seminatural ecosystems, for example the forests located in the east and west, grasslands to the north, and the Bohai and Yellow Seas in the northeast and east of the NCP. The total $\mathrm{NH}_{\mathrm{x}}$ deposition is $43.5 \mathrm{~kg}$ $\mathrm{N} \mathrm{ha}^{-1} \mathrm{yr}^{-1}$ with $\mathrm{NH}_{3}$ and $\mathrm{NH}_{4}{ }^{+}$deposition contributing to $54.7 \%$ and $45.3 \%$, respectively. This high $\mathrm{NH}_{\mathrm{x}}$ deposition together with moderate $\mathrm{NO}_{\mathrm{x}}$ deposition (Zhang et al., 2008; Shen et al., 2009) is another reason for reducing excess $\mathrm{N}$ fertilizer application in the
NCP: the overuse of N fertilizer in China (including the NCP) has caused significant acidification of croplands (Guo et al., 2010), large $\mathrm{NH}_{3}$ volatilization loss and substantial $\mathrm{N}_{2} \mathrm{O}$ emission (Ju et al., 2009; Zhu and Chen, 2002) and groundwater nitrate pollution (Zhang et al., 1996).

It should be stressed that all of the data in the Fig. 6 were calculated by simple estimation or were approximate values from the literature. For example, the dry deposition values were not obtained from in situ measurement, but from a simple inferential method. The ratio of wet deposition of $\mathrm{NH}_{3}$ to $\mathrm{NH}_{\mathrm{x}}$ was also an empirical value. Besides, the dry and wet deposited $\mathrm{NH}_{4}{ }^{+}$may include that from sources other than $\mathrm{N}$ fertilizer, e.g., livestock manure, plants and soils. Thus, the dry and wet deposited $\mathrm{NH}_{4}{ }^{+}$ from $\mathrm{N}$ fertilizer in the NCP may be overestimated, while the transported $\mathrm{NH}_{4}{ }^{+}$may be underestimated. To obtain a more precise value for $\mathrm{NH}_{3}$ emission, transport, transformation and deposition in the NCP, we strongly recommend in situ measurements of atmospheric concentrations, emissions, and wet and dry deposition of $\mathrm{NH}_{\mathrm{x}}$. Moreover, deposition models such as FRAME (Singers et al., 1998; Kryza et al., 2009), MM5/CMAQ (Wu et al., 2008a, b) should be used to give more detailed data on $\mathrm{NH}_{\mathrm{X}}$ net fluxes and transportation between the NCP and surrounding regions.

\subsection{The benefits of agricultural $\mathrm{NH}_{3}$ emission control to atmospheric PM reduction}

Using an inorganic aerosol equilibrium model proposed by Ansari and Pandis (1998), we estimated the response of secondary inorganic PM (sum of particulate $\mathrm{NH}_{4}{ }^{+}, \mathrm{NO}_{3}{ }^{-}$and $\mathrm{SO}_{4}{ }^{2-}$ ) to $\mathrm{NH}_{3}$ concentrations at our sites. Data of seasonal concentrations of $\mathrm{NH}_{3}$, $\mathrm{HNO}_{3}$, particulate $\mathrm{NH}_{4}{ }^{+}, \mathrm{NO}_{3}{ }^{-}$and $\mathrm{SO}_{4}{ }^{2-}$ as well as air temperature and relative humidity at $\mathrm{QZ}$ and $\mathrm{SZ}$ were used to calculate the input parameters for the model (Table 5). According to the model, although PM was sensitive to both $\mathrm{H}_{2} \mathrm{SO}_{4}$ and $\mathrm{HNO}_{3}(\mathrm{~d}(\mathrm{PM}) /$ $\mathrm{d}\left(\mathrm{SO}_{4}{ }^{2-}\right)=1-1.34$ and $\left.\mathrm{d}(\mathrm{PM}) / \mathrm{d}\left(\mathrm{NO}_{3}{ }^{-}\right)=0.9-1.3\right)$ there was a nonlinear response to $\mathrm{NH}_{3}\left(\mathrm{~d}(\mathrm{PM}) / \mathrm{d}\left(\mathrm{NH}_{3}\right)=0.2-3.5\right)$ in all four seasons at $\mathrm{SZ}$ and in spring and summer at QZ. As shown in Table 5, the free $\mathrm{NH}_{3}\left(\left[\mathrm{NH}_{3}(\mathrm{~g})\right]+\left[\mathrm{NH}_{4}{ }^{+}(\mathrm{a})\right]-2\left[\mathrm{SO}_{4}{ }^{2-}\right.\right.$ (a) $\left.]\right)$ concentrations were very high in most seasons at both sites. Therefore, it can be inferred that inorganic PM would be sensitive to $\mathrm{H}_{2} \mathrm{SO}_{4}$ or $\mathrm{HNO}_{3}$. As the total nitrate concentrations $\left(\left[\mathrm{HNO}_{3}(\mathrm{~g})\right]+\left[\mathrm{NO}_{3}{ }^{-}(\mathrm{a})\right]\right)$ were also high at the sites, which suggests that further formation of $\mathrm{NH}_{4} \mathrm{NO}_{3}$ is possible, there would be a nonlinear response of $\mathrm{PM}$ to $\mathrm{NH}_{3}$. This indicates that reducing $\mathrm{NH}_{3}$ concentrations could be an effective method for alleviating secondary inorganic PM pollution in the $\mathrm{NCP}$, especially in suburban or urban areas. Using the CMAQ model, Liu et al. (2005) argued that control $\mathrm{NH}_{3}$ emission was one of the most efficient ways of reducing $\mathrm{PM}$ pollution in north China, besides the reduction of primary $\mathrm{SO}_{2}, \mathrm{NO}_{\mathrm{x}}$ and aerosol emissions. This is also the case for $\mathrm{SO}_{2}$ and $\mathrm{NO}_{\mathrm{x}}$ as precursors of secondary particles. However, although $\mathrm{PM}_{10}$ is routinely measured in large Chinese cities, $\mathrm{NH}_{3}$, an important precursor of secondary particles, is not (Chan and Yao, 2008). Considering the high $\mathrm{PM}_{10}$ and secondary inorganic particle concentrations at both rural and

Table 5

Temperature and relative humidity, averaged concentrations (ppb) of free ammonia $\left(\mathrm{NH}_{3}{ }^{\mathrm{F}}\right)$ and total nitrate $\left(\mathrm{HNO}_{3}{ }^{\mathrm{T}}\right)$ and gas ratio $(\mathrm{GR})$ in four seasons at QZ and SZ.

\begin{tabular}{|c|c|c|c|c|c|c|c|c|c|c|}
\hline \multirow[t]{2}{*}{ Season } & \multicolumn{5}{|l|}{$\mathrm{QZ}$} & \multicolumn{5}{|l|}{ SZ } \\
\hline & $\mathrm{T}$ & $\mathrm{RH}$ & $\mathrm{NH}_{3}{ }^{\mathrm{F}}$ & $\mathrm{HNO}_{3}{ }^{\mathrm{T}}$ & $\overline{G R}$ & $\mathrm{~T}$ & $\mathrm{RH}$ & $\mathrm{NH}_{3}{ }^{\mathrm{F}}$ & $\mathrm{HNO}_{3}{ }^{\mathrm{T}}$ & $\overline{G R}$ \\
\hline Spring & Medium & Low & 24.1 & 8.9 & 2.7 & Medium & Low & 19.1 & 8.4 & 2.3 \\
\hline Summer & High & High & 38.7 & 8.0 & 4.8 & High & High & 26.3 & 8.0 & 3.3 \\
\hline Autumn & Medium & High & 25.3 & 10.1 & 2.5 & Medium & High & 11.8 & 6.7 & 1.7 \\
\hline Winter & Low & Low & 19.1 & 12.4 & 1.5 & Low & Low & 5.7 & 5.0 & 1.1 \\
\hline
\end{tabular}

Note: T: air temperature, $\mathrm{RH}$ : relative humidity, $\mathrm{NH}_{3}{ }^{\mathrm{F}}=\left[\mathrm{NH}_{3}(\mathrm{~g})\right]+\left[\mathrm{NH}_{4}{ }^{+}(\mathrm{a})\right]-2\left[\mathrm{SO}_{4}{ }^{2-}(\mathrm{a})\right], \mathrm{HNO}_{3}{ }^{\mathrm{T}}=\left[\mathrm{HNO}_{3}(\mathrm{~g})\right]+\left[\mathrm{NO}_{3}{ }^{-}(\mathrm{a})\right], \mathrm{GR}^{-}=\mathrm{NH}_{3}{ }^{\mathrm{F}} / \mathrm{HNO}_{3}{ }^{\mathrm{T}}$. 
suburban sites in the NCP (Table 2) and the dependence of secondary inorganic particles on local $\mathrm{NH}_{3}$ emissions, we suggest that $\mathrm{NH}_{3}$ emissions from agricultural sources should be measured and controlled to improve air quality in the NCP.

\section{Conclusions and summary}

(1) Atmospheric $\mathrm{NH}_{3}$ and particulate $\mathrm{NH}_{4}{ }^{+}$concentrations were very high at six agricultural sites in the North China Plain, with annual mean concentrations of $\mathrm{NH}_{3}$ and $\mathrm{NH}_{4}{ }^{+}$of 15.6 and $12.4 \mu \mathrm{g} \mathrm{m}^{-3}$, respectively, reflecting high $\mathrm{NH}_{3}$ emission intensities from agriculture.

(2) Both $\mathrm{NH}_{3}$ and particulate $\mathrm{NH}_{4}{ }^{+}$concentrations showed distinct spatio-temporal variations. Compared with suburban sites, higher $\mathrm{NH}_{3}$ and $\mathrm{NH}_{4}{ }^{+}$concentrations were found at rural sites due to large $\mathrm{NH}_{3}$ emissions from fertilizer $\mathrm{N}$. $\mathrm{NH}_{3}$ concentrations were highest in summer and lowest in winter at both rural and suburban sites, while highest $\mathrm{NH}_{4}{ }^{+}$concentrations occurred in winter and summer at all six sites. Nitrogen fertilizer application, air temperature and gas-to-particle conversion reactions have important influences on this seasonality.

(3) Annual mean concentrations of secondary $\mathrm{NH}_{4}{ }^{+}$related particles (sum of $\mathrm{NH}_{4}{ }^{+}, \mathrm{SO}_{4}{ }^{2-}$ and $\mathrm{NO}_{3}{ }^{-}$) in $\mathrm{PM}_{10}$ were $36.2-80.4 \mu \mathrm{g} \mathrm{m}^{-3}$ and accounted for $26.1-41.3 \%$ of the $\mathrm{PM}_{10}$ concentration at the sites. Serious secondary inorganic particle pollution in the NCP is a reflection of the high emission intensities of $\mathrm{NH}_{3}, \mathrm{NO}_{\mathrm{x}}$ and $\mathrm{SO}_{2}$ in this region. High $\mathrm{NH}_{3} / \mathrm{NH}_{\mathrm{x}}$ ratios and the dependence of secondary inorganic PM concentrations on $\mathrm{NH}_{3}$ concentrations suggests that controlling $\mathrm{NH}_{3}$ emission from agricultural sources could be an efficient way to reduce secondary inorganic particle pollution in the $\mathrm{NCP}$, besides the reduction of $\mathrm{SO}_{2}$ and $\mathrm{NO}_{\mathrm{x}}$ emissions from industry, power plants and transport.

(4) $\mathrm{NH}_{\mathrm{x}}$ dry and wet deposition averaged $43.5 \mathrm{~kg} \mathrm{~N} \mathrm{ha}^{-1} \mathrm{yr}^{-1}$ at the sites. The heavy $\mathrm{NH}_{\mathrm{x}}$ pollution and deposition should be considered in non-point source pollution (e.g., eutrophication) control and integrated cropland $\mathrm{N}$ management.

\section{Acknowledgements}

The research was supported by the "One Hundred Talents Program" from Chinese Academy of Sciences, the National Natural Science Foundation of China (NSFC) (41071151 and 40771188), the Innovative Group Grants from NSFC (30821003), and the SinoGerman project (DFG Research Training Group, GK1070). Rothamsted Research is an institute of the UK Biotechnology and Biological Sciences Research Council.

\section{References}

Adams, P.J., Seinfeld, J.H., 2001. General circulation model assessment of direct radiative forcing by the sulfate-nitrate-ammonium-water inorganic aerosol system. Journal of Geophysical Research 106, 1097-1111.

Aneja, V.P., Murthy, A.B., Battye, W., Battye, R., Benjey, W.G., 1998. Analysis of ammonia and aerosol concentrations and deposition near the free troposphere at Mt. Mitchell, NC, U.S.A. Atmospheric Environment 32, 353-358.

Ansari, A.S., Pandis, S.N., 1998. Response of inorganic PM to precursor concentrations. Environmental Science \& Technology 32, 2706-2714.

Asman, W.A.H., Sutton, M.A., Schjorring, J.K., 1998. Ammonia: emission, atmospheric transport and deposition. New Phytologist 139, 27-48.

Asman, W.A.H., 2001. Modelling the atmospheric transport and deposition of ammonia and ammonium: an overview with special reference to Denmark. Atmospheric Environment 35, 1969-1983.

Bergström, A.-K., Jansson, M., 2006. Atmospheric nitrogen deposition has caused nitrogen enrichment and eutrophication of lakes in the northern hemisphere. Global Change Biology 12, 635-643.

BEPB (Beijing Environmental Protection Bureau), 2010. Annual report of environmental Status in Beijing. Available at: http://www.bjepb.gov.cn/ (accessed December, 2009).
Bouwman, A.F., Lee, D.S., Asman, W.A.H., Dentener, F.J., Van Der Hoek, K.W., Olivier, J.G.J., 1997. A global high-resolution emission inventory for ammonia. Global Biogeochemical Cycles 11, 561-587.

Bouwman, A.F., Van Vuuren, D.P., Derwent, R.G., Posch, M., 2002. A global analysis of acidification and eutrophication of terrestrial ecosystems. Water, Air, and Soil Pollution 141, 349-382.

Buijsman, E., Aben, J.M.M., Van Elzakker, B.G., Mennen, M.G., 1998. An automatic atmospheric ammonia network in the Netherlands. Atmospheric Environment 32, 317-324.

Burkhardt, J., Sutton, M.A., Milford, C., Storeton-West, R.L., Fowler, D., 1998. Ammonia concentrations at a site in Southern Scotland from $2 \mathrm{yr}$ of continuous measurements. Atmospheric Environment 32, 325-331.

Cai, G.X., Chen, D.L., Ding, H., Pacholski, A., Fan, X.H., Zhu, Z.L., 2004. Nitrogen losses from fertilizers applied to maize, wheat and rice in the North China Plain. Nutrient Cycling in Agroecosystems 63, 187-195.

Cao, J.J., Zhang, T., Chow, J.C., Watson, J.G., Wu, F., Li, H., 2009. Characterization of atmospheric ammonia over Xi'an, China. Aerosol and Air Quality Research 9, 277-289.

Cape, J.N., Tang, Y.S., van Dijk, N., Love, L., Sutton, M.A., Palmer, S.C.F., 2004. Concentrations of ammonia and nitrogen dioxide at roadside verges, and their contribution to nitrogen deposition. Environmental Pollution 132, 469-478.

Chan, C.K., Yao, X.H., 2008. Air pollution in mega cities in China. Atmospheric Environment 42,1-42.

Clarisse, L., Clerbaux, C., Dentener, F., Hurtmans, D., Coheur, P.F., 2009. Global ammonia distribution derived from infrared satellite observations. Nature Geoscience 2, 479-483.

Denmead, O.T., Freney, J.R., Dunin, F.X., 2008. Gas exchange between plant canopies and the atmosphere: case-studies for ammonia. Atmospheric Environment 42, 3394-3406.

Edgerton, E.S., Saylor, R.D., Hartsell, B.E., Jansen, J.J., Hansen, D.A., 2007. Ammonia and ammonium measurements from the southeastern United States. Atmospheric Environment 41, 3339-3351.

Erisman, J.W., Schaap, M., 2004. The need for ammonia abatement with respect to secondary PM reductions in Europe. Environmental Pollution 129, 159-163.

Galloway, J.N., Dentener, F.J., Capone, D.G., Boyer, E.W., Howarth, R.W., Seitzinger, S.P., Asner, G.P., Cleveland, C.C., Green, P.A., Holland, E.A., Karl, D.M., Michaels, A.F., Porter, J.H., Townsend, A.R., Vöosmarty, C.J., 2004. Nitrogen cycles: past, present and future. Biogeochemistry 70, 153-226.

Gietl, J.K., Tritscher, T., Klemm, O., 2008. Size-segregated analysis of $\mathrm{PM}_{10}$ at two sites, urban and rural, in Münster (Germany) using five-stage Berner type impactors. Atmospheric Environment 42, 5721-5727.

Guo, J.H., Liu, X.J., Zhang, Y., Shen, J.L., Han, W.X., Zhang, W.F., Christie, P., Goulding, K.W.T., Vitousek, P.M., Zhang, F.S., 2010. Significant acidification in major Chinese croplands. Science 327, 1008-1010.

Hanson, P.J., Lindberg, S.E., 1991. Dry deposition of reactive nitrogen compounds: a review of leaf, canopy and non-foliar measurements. Atmospheric Environment 25A, 1615-1634.

Haywood, J., Boucher, O., 2000. Estimates of the direct and indirect radiative forcing due to tropospheric aerosols: a review. Reviews of Geophysics 38, 513-543.

He, K.B., Yang, F.M., Ma, Y.L., Zhang, Q., Yao, X.H., Chan, C.K., Cadle, S., Chan, T., Mulawa, P., 2001. The characteristics of $\mathrm{PM}_{2.5}$ in Beijing, China. Atmospheric Environment 35, 4959-4970.

Hong, Y.M., Lee, B.K., Park, K.J., Kang, M.H., Jung, Y.R., Lee, D.S., Kim, M.G., 2002. Atmospheric nitrogen and sulfur containing compounds for three sites of South Korea. Atmospheric Environment 36, 3485-3494.

Horváth, L., Sutton, M.A., 1998. Long-term record of ammonia and ammonium concentrations at K-Puszta, Hungary. Atmospheric Environment 32, 339-344.

Ju, X.T., Xing, G.X., Chen, X.P., Zhang, S.L., Zhang, L.J., Liu, X.J., Cui, Z.L., Yin, B. Christie, P., Zhu, Z.L., Zhang, F.S., 2009. Reducing environmental risk by improving $\mathrm{N}$ management in intensive Chinese agricultural systems. PNAS 106, 3041-3046.

Khoder, M.I., 2002. Atmospheric conversion of sulfur dioxide to particulate sulfate and nitrogen dioxide to particulate nitrate and gaseous nitric acid in an urban area. Chemosphere 49, 675-684.

Kryza, M., Dore, A.J., Błás, M., Sobik, M., 2009. Application of a Lagrangian Model FRAME to estimate reduced nitrogen deposition and ammonia concentrations in Poland. In: Sutton, M.A., Reis, S., Baker, S.M.H. (Eds.), Atmospheric Ammonia. Springer, Dordrecht, The Netherlands, pp. 359-366.

Liu, Y., Li, W.L., Zhou, X.J., 2005. Simulation of secondary aerosols over North China in summer. Science in China, Series D Earth Sciences 48 (S2), 185-195.

Liu, X.J., Ju, X.T., Zhang, Y., He, C.E., Kopsch, J., Zhang, F.S., 2006. Nitrogen deposition in agroecosystems in the Beijing area. Agriculture, Ecosystems and Environment $113,370-377$.

Lu, Z., Streets, D.G., Zhang, Q., Wang, S., Carmichael, G.R., Cheng, Y.F., Wei, C., Chin, M. Diehl, T., Tan, Q., 2010. Sulfur dioxide emissions in China and sulfur trends in East Asia since 2000. Atmospheric Chemistry and Physics 10, 6311-6331.

McCulloch, R.B., Few, G.S., Murray, G.C., Aneja, J. Aneja, V.P., 1998. Analysis of ammonia, ammonium aerosols and acid gases in the atmosphere at a commercial hog farm in eastern North Carolina, USA. Environmental Pollution 102 (S1), 263-268.

Meng, Z.Y., Ding, G.A., Xu, X.B., Xu, X.D., Yu, H.Q., Wang, S.F., 2008. Vertical distributions of $\mathrm{SO}_{2}$ and $\mathrm{NO}_{2}$ in the lower atmosphere in Beijing urban areas, China. Science of the Total Environment 390, 456-465.

MEPC (Ministry of Environmental Protection of China), 2010. Ambient air quality in major cities in China in the first half year of 2010. Available at: http://www.mep. gov.cn/ (accessed December, 2010). 
Pinder, R.W., Adams, P.J., 2007. Ammonia emission controls as a cost-effective strategy for reducing atmospheric particulate matter in the eastern United States. Environmental Science \& Technology 41, 380-386.

Richter, A., Burrows, J.P., Nüß, H., Granier, C., Niemeier, U., 2005. Increase in tropospheric nitrogen dioxide over China observed from space. Nature 437, 129-132.

Robarge, W.P., Walker, J.T., McCulloch, R.B., Murray, G., 2002. Atmospheric concentrations of ammonia and ammonium at an agricultural site in the southeast United States. Atmospheric Environment 36, 1661-1674.

Shen, J.L., Tang, A.H., Liu, X.J., Fangmeier, A., Goulding K.T.W., Zhang, F.S., 2009. High concentrations and dry deposition of reactive nitrogen species at two sites in the North China Plain. Environmental Pollution 157, 3106-3113.

Singers, R., Sutton, M.A., Weston, K.J., 1998. A multi-layer model to describe the atmospheric transport and deposition of ammonia in Great Britain. Atmospheric Environment 32, 393-399.

Stevens, C.J., Dise, N.B., Mountford, J.O., Gowing, D.J., 2004. Impact of nitrogen deposition on the species richness of grasslands. Science 303, 1876-1879.

Streets, D.G., Waldhoff, S.T., 2000. Present and future emissions of air pollutants in China: $\mathrm{SO}_{2}, \mathrm{NO}_{\mathrm{x}}$, and $\mathrm{CO}$. Atmospheric Environment 34, 363-374.

Sutton, M.A., Erisman, J.W., Dentener, F., Moller, D., 2008. Ammonia in the environment: from ancient times to the present. Environmental Pollution 156, 583-604.

Walker, J.T., Whitall, D.R., Robarge, W., Paerl, H.W., 2004. Ambient ammonia and ammonium aerosol across a region of variable ammonia emission density. Atmospheric Environment 38, 1235-1246.

Wang, Y., Zhuang, G.S., Tang, A.H., Yuan, H., Sun, Y.L., Chen, S., Zheng, A.H., 2005. The ion chemistry and the source of $\mathrm{PM}_{2.5}$ aerosol in Beijing. Atmospheric Environment 39, 3771-3784.
Wu, S.Y., Krishnan, S., Zhang, Y., Anejia, V., 2008a. Modeling atmospheric transport and fate of ammonia in North Carolina-Part I: evaluation of meteorological and chemical predictions. Atmospheric Environment 42, 3419-3436.

Wu, S.Y., Hu, J.L., Zhang, Y., Aneja, V.P., 2008b. Modeling atmospheric transport and fate of ammonia in North Carolina-Part II: effect of ammonia emissions on fine particulate matter formation. Atmospheric Environment 42, 3437-3451.

Wu, Z.J., Hu, M., Shao, K.S., Slanina, J., 2009. Acidic gases, $\mathrm{NH}_{3}$ and secondary inorganic ions in $\mathrm{PM}_{10}$ during summertime in Beijing, China and their relation to air mass history. Chemosphere 76, 1028-1035.

Yamamoto, N., Nishiura, H., Honjo, T., Ishikawa, Y., Suzuki, K., 1995. A long-term study of atmospheric ammonia and particulate ammonium concentrations in Yokohama, Japan. Atmospheric Environment 29, 97-103.

Yan, X.Y., Akimoto, H., Ohara, T., 2003. Estimation of nitrous oxide, nitric oxide and ammonia emissions from croplands in east, southeast and South Asia. Global Change Biology 9, 1080-1096.

Zhang, W.L., Tian, Z.X., Zhang, N., Li, X.Q., 1996. Nitrate pollution of groundwater in northern China. Agriculture, Ecosystems and Environment 59, 223-231.

Zhang, Y., Dore, A.J., Ma, L., Liu, X.J., Ma, W.Q., Cape, J.N., Zhang, F.S., 2010. Agricultural ammonia emissions inventory and spatial distribution in the North China Plain. Environmental Pollution 158, 490-501.

Zhang, Y., Liu, X.J., Fangemeier, A., Goulding, K.T.W., Zhang, F.S., 2008. Nitrogen inputs and isotopes in precipitation in the North China Plain. Atmospheric Environment 42, 1436-1448.

Zhu, Z.L., Chen, D.L., 2002. Nitrogen fertilizer use in China - contributions to food production, impacts on the environment and best management strategies. Nutrient Cycling in Agroecosystems 63, 117-127. 